gene. The Senate's programme is therefore directed principally towards setting up genetic screening and counselling centres to identify couples whose children may be at risk, and another important part of the legislation is the provision of $\$ 42$ million over the next three years to support research into the diagnosis, treatment and control of the disease.

Senator Edward M. Kennedy's public health subcommittee, which handled the legislation, was evidently impressed by witnesses who described the results of treating sufferers of sickle cell anaemia with urea or cyanate compounds. Such treatment is essentially aimed at overcoming the so-called sickle cell crisisthe painful and debilitating symptom of the disease caused when the red blood cells lack oxygen and form themselves into the sickle shape, severely restricting the flow of blood to tissues-but it is the subject of heated debate among many physicians. The committee report talks of a possible breakthrough in this area, and the bill authorizes the Department of Health, Education and Welfare to spend \$5 million on research in 1973 , $\$ 10$ million in 1974 and $\$ 15$ million in 1975.

Since the cause of the disease is genetic, it is incurable (in spite of a curious phrase which crept into the committee report to the effect that "further work in the field of genetic engineering also offers scope in the struggle to conquer this crippling malady"), and the Senate's bill therefore lays considerable emphasis on the provision of screening and genetic counselling centres to pinpoint carriers of the sickle cell trait and to advise couples who both carry the trait of the risks of bearing children who have the disease. Kennedy's subcommittee in fact increased the provision for setting up such clinics by the Department of Health, Education and Welfare by bumping up the funding to $\$ 25$ million in $1973, \$ 30$ million and $\$ 40$ million in 1975 , chiefly on the basis that it would cost about $\$ 60$ million to establish only ten such centres.

The bill also sees a role for the Department of Defense and the Veterans Administration in the fight against sickle cell anaemia, authorizing the defence department to conduct a screening programme, and giving the Veterans Administration a total of $\$ 12$ million over the next three years for research.

If a similar bill is passed by the House - companion legislation was introduced by the District of Columbia delegate Walter Faunteroy and Mr Paul G. Rogers's health subcommittee has already conducted hearings on the bill -the Administration could be put in something of an embarrassing position. It was President Nixon who set the ball rolling in his health message to Congress last February, when he referred to the "shameful fact that the causes of this disease have been largely neglected throughout our history", but the bill that he is now likely to get back from Congress will contain expenditures many times greater than the present $\$ 6$ million a year that is devoted to research, treatment, screening and counselling. Since there have already been many charges that the disease has been neglected because it is confined chiefly to blacks, the Administration would find it very difficult to oppose the legislation, even though Nixon now seems to enjoy testing his muscle with Congress over all sorts of legislation.

\section{Shorf Noies}

\section{Ocean Dumping}

THE Senate agreed recently, by a vote of 73 to 0 , to a bill designed to prohibit unregulated dumping of wastes into the oceans around the United States: The bill is in most respects the same as that passed in September by the House of Representatives, except that a provision designed to set up marine sanctuaries in some ocean areas has been removed. The designation of marine sanctuaries was intended by the House of Representatives to preserve intact areas of ocean for ecological, recreational or aesthetic reasons, and it would have led to the control of activities such as oil drilling in the designated regions. The provision was opposed in the Senate because the sanctuaries would have been set up in international waters - a suggestion to which senators objected because it may violate international law and also it may be viewed by other countries as "creeping jurisdiction" over areas of the high seas. The Administration also opposed that part of the House bill because it would have cost about $\$ 10$ million to institute.

\section{Nutrition}

WhEN Dr Robert B. Choate, a nutrition consultant, told a Senate Committee last year that many leading brands of breakfast cereal are over-advertised and under-nutritious, his revelations were greeted with scorn from the multimillion dollar industry (see Nature, 227, $548 ; 1970)$. Nevertheless, while trying to belittle $\mathrm{Mr}$ Choate's analyses, the industry has been busy reformulating its products, and $\mathrm{Mr}$ Choate recently published a revised chart showing that twenty-six of the previously nonnutritious products have been considerably fortified with nutrients. Two of the most heavily advertised brands-Kellogg's Corn Flakes and Kellogg's Rice Krispies-are, however, among the bottom 10 per cent of all breakfast products in nutrient value, and on $\mathrm{Mr}$ Choate's analysis, can still be considered as "empty calories". The Food and Drug Administration has been developing nutrient guidelines for cereals for the past eighteen months, but "industry pressure and the lassitude of academia make us wonder whether the Food and Drug Administration will ever establish nutrition guidelines which can serve as a basis for ethical advertising slogans", Mr Choate tartly remarked.

\section{Shuttle}

A SERIES of meetings was held recently between officials of NASA and the European Space Conference to discuss possible areas for cooperation on the post-Apollo space programme. The meeting is said to have produced a list of projects on which Europe and the United States may be able to cooperate. They include major responsibility for development of the space tug, subsystems of the shuttle and supporting studies in related technology areas. It is now up to members of the European Space Conference to select specific projects on which to cooperate, and another meeting has been fixed for February for further discussions.

\section{$A E C$ and the Environment}

Proposed amendments to the Atomic Energy Commission's regulatory procedure, published in the Federal Register recently, further extend the agency's control over the environmental consequences of building nuclear power plants. The AEC is intending to prohibit the clearing of land and other site preparations, such as construction of non-nuclear facilities such as turbine buildings, until a construction permit has been issued. The chief effect of the new regulations, which are at present open to public comment, would be to make such activities a part of the review of the environmental impact of a proposed plant.

\section{Arms Race}

THE Federation of American Scientists, a consistent and vocal critic of the arms race, last week proposed that the President of the United States must have the approval of Congress before unleashing nuclear weapons in a first strike situation. The federation, which has always been opposed to the first use of nuclear weapons, has proposed this policy in conjunction with the War Powers Act introduced into Congress recently by Senators Javits, Stennis and Eagleton. The federation believes that such an arrangement would have the advantage of building into the nuclear arsenal an extra safeguard, and it would also have the added advantage of reducing international tensions during crises such as the Cuban missile crisis, since the first use of nuclear weapons by the United States would be ruled out unless Congress had given its express approval. 